Journal of Economics and Behavioral Studies

Vol. 4, No. 6, pp. 344-353, June 2012 (ISSN: 2220-6140)

\title{
Measuring Goods Quality in Iran's Intra- Industry Trade with G-8 Member States
}

\author{
*Masoud Nonejad, Maryam Haghjoo \\ Islamic Azad University: Shiraz Branch, Iran \\ *mnonejad.Iaushiraz@yahoo.com
}

\begin{abstract}
As economic integration in East Asia progresses, trade patterns within region are displaying an ever - greater complexity. Though inter - industry trade still accounts for the majority, its share in overall trade is declining. Instead, intra - industry trade (IIT), which can be further divided into horizontal IIT (HIIT) and vertical IIT (VIIT) is growing in importance. In this paper, we set out and examine different kinds of intra- industry trade between Iran and G-8 member states by comparing the Greenway, Hine and Milner (1994) and Fontagne and Freudenberg (1997) approaches to disentangling vertical and horizontal intra industry trade. Then we introduce and examine a new index from Azhar and Elliott to define product quality types between Iran and G-8 members for the time of 2001-2009. Result shows that a significant share of Iran's industry trade with G-8 state members has been assigned to vertical intra - industry trade. With regarded to Azhar and Elliott index, the main share of intra- industry trade consists of low quality goods.
\end{abstract}

Key words: intra-industry trade, horizontal and vertical distinction, product quality, Iran, $G-8$.

\section{Introduction}

For more than four decades theoretical and empirical researchers in the field of international trade have been keenly interested in two way trade of products belonging to the same industry, that is intra - industry trade (IIT), with theories of comparative advantage, or Heckscher -Ohlin factor endowment, focusing on inter - industry trade. Ricardo's comparative advantage model states that countries with different comparative advantages engaging in trade will profitably benefit from it. Both types of trade models assume that goods traded are homogeneous, and the country will therefore only either export goods within the same industry or only import these goods, but not simultaneously export and import goods within in the same industry. One important observation in international trade is that much of the post-war expansion of trade has taken the form of intra-industry trade (IIT); commonly define as the simultaneous imports and exports of goods from the same industry. Empirical work on the measurement of intra-industry trade began in the mid1960s with Balassa (1966) and the most well known work on intra industry trade by Grubel and Lloyd (1975). This empirical work has led to a renewal of interest in the theoretical models of Krugman (1979), Lancaster (1980), Helpman (1981), and Falvey (1981), Falvey and Kierzkowski(1985), and Flam and Helpman(1987) have sought determinants of intra-industry trade and demonstrate that large number of firms will produce varieties of different quality. The constant increase in products' quality is an important competitive driver influencing firms' success in the global market. In recent years empirical studies (Bernard and Jensen, 2001; Bernard et al., 2005; Hallak and Schott, 2005) offer clear evidence of the increasing importance of intra-industry trade based on vertically differentiated products. In the economic literature, the concept of quality does not refer only to particular physical feature of the products, such as materials or technology embedded. For Hallak and Schott (2005) product quality refers to all the features, tangible and intangible, influencing consumers' economic valuation. To do so, the first stage is to develop a methodology for differentiating between qualitatively different bilateral trades in goods from the same industry. The second stage is to document the levels, and test for the determinants of, vertical and horizontal IIT for trade relationships. A third stage is suggested by Azhar and Elliott. This index (AE) has symmetrical limits, is scaled equally in both upper and lower bounds, and can measure the dispersion of product quality in IIT. This type of trade not only increases consumers' options but also increases the level of competition among producers of a given product in different countries. Given the significant and increasing role of intra-industry trade in foreign trade, it is of vital importance to pay attention seriously to the role of this phenomenon in foreign trade pattern. As a result, the present study examines the Iran's intra-industry trade with G-8 state members 
during 2001-2009. To do so, the data collected from Tehran's Trade, Industry and Mine Chamber for different products at a four-digit level based on the Harmonized System will analyzed and used in the study.

\section{Literature Review}

International trade patterns are traditionally explained by the Heckscher-Ohlin (HO) model, which predicts that a particular country will exports the products that use its relatively abundant factor intensively and imports the products that use its relatively less abundant factor intensively. According to the HO model, similar countries have little reason to trade, particularly if there are similar products. The IIT literature began in 1960s when Balassa (1966) analyzed the trade within the industries of customs union in Europe. Grubel and Lloyd (1975) introduced a comprehensive index to measure IIT. The pioneering works on IIT (Krugman, 1979, 1980, 1981; Lancaster, 1980; Helpman, 1981) exclude the idea that traditional theories could explain IIT. The basic structure of horizontal IIT models is that products are not differentiated by the quality, but the attributes (Krugman, 1979; Lancaster, 1980; Helpman, 1981; Brander and Krugman, 1983; Eaton and Kierzkowski, 1984). Krugman (1979) consider that consumers have similar preference (Neo-Chamberlinian models). The model of Krugman demonstrates that IIT occurs between identical economies (geographical proximity). The model of Lancaster (1980), called "Neo-Hotelling model" shows that consumers have a preference map, i.e. "ideal variety". Brander and Krugman (1983) demonstrated that it is possible to explain IIT with Cournot style. The authors incorporate transport costs and the reciprocal dumping. Following Lancaster model, Eaton and Kierzkowski (1984) explain that IIT is determined by the prices and the distance between the product spectrums. In vertical IIT models, the quality is assumed to be directly related to the capital-labor ratio. A capital-rich country is likely to produce higher-quality products; while a labor-rich country is likely to produce lower-quality products. The Neo Heckscher-Ohlin model of vertical IIT (Falvey, 1981, and Falvey and Kierzkowski, 1985), the capital endowment is assumed industry-specific with at least one sector producing differentiated products in terms of quality (vertical differentiated product). According to Falvey and Kierzkowski (1985), the unequal income is assuming a source of the demand for variety of vertically differentiated products, a larger difference in income will increase the share of vertical IIT. Shaked and Sutton (1984) explained the VIIT with the "natural oligopoly". The quality is associated on fixed costs. Demand for each quality of the product depends on the distribution of income. Firms face three-part decision process - entry, quality and price. Havrlsyshyn and Kunzel (1997) analyzed the intra-industry trade of Arabcountries. The authors concluded that Arab -region overall does not have highly advanced industrial base, with an average IIT index of 0.25 for the period 1992-1994. The second stage involves the sunk cost of research and development. Only a few empirical studies analyze one industry-specific of intra-industry trade (see for example Clark, 2006, Wakasugi, 2007, Leitão and Faustino, 2009). The studies of Clark, 2006, Wakasugi, 2007 and Leitão and Faustino, 2009 show the importance of fragmentation.

The study of Clark (2006) demonstrated that globalization will continue to reinforce the idea that there are more efficient places (i.e with low production costs) and that is linked with vertical specialization. Clark used a Tobit and Probit specifications at a country and industry level. Wakasugi (2007) constructed an index of vertical intra-industry trade to measure the fragmentation of production. The author used a gravity model and analyzed the impact of VIIT in East Asia, NAFTA, and European Union. Wakasugi concluded that fragmentation increased with intra-industry trade. The study of Leitão and Faustino (2009) examines the determinants of intra-industry trade in the automobile component sector in Portugal. This manuscript considers Portuguese trade in automobile sector between European Union (EU-27), the BRIC (Brazil, India and China), and United States between 1995 and 2006. The authors using a panel data (static and dynamic panel data: GMM-System). This study concludes that IIT occurs more frequently among countries that are similar endowments. They also show that trade increases if the transportation costs decrease. Yoshida, Leitão and Faustino (2009) consider the vertical intra-industry trade (VIIT) between Japan and Various European countries. The authors conclude that IIT between European countries and Japan increases with their corresponding Japanese FDI (foreign direct investment), especially for new EU member countries. Zhang and Clark (2009) investigate HIIT and VIIT for the case of United States. This study uses both industry and country-specific characteristics as explanatory variables. The study of Zhang and Clark show that HIT will have relatively low factor adjustment costs when compared with the VIIT. The results have support for new trade theories and traditional factor endowment-based (Heckscher-Ohlin model). Chang (2009) examines the main factors of HIIT and VIIT including investment approaches of a firm in the industry of information 
technology for Asian, European and US markets. The study uses time series data over the period of 19962005 for said variables in sample economies. The results indicate that vertical intra-industry trade is playing its significant role among Asian and European markets while horizontal intra-industry trade is significant between Asian and US. Leitão and Faustino (2008) analyses the determinants of intra-industry trade (IIT) in the Portuguese food-processing sector. The study uses both industry and country-specific characteristics as explanatory variables.

The results indicate that IIT in this sector is a positive function of the difference in GDP per capita between Portugal and its European trade partners. Statistically strong evidence is also found that this trade is influenced by the geographical distance between trading partners. Using industry-specific characteristics, the results also show that this type of trade is negatively influenced by industrial concentration. In addition, the foreign direct investment inflows have a positive influence on Portuguese bilateral IIT, although this variable is not statistically significant. Nafari and Rasekhi (2002) employed Grubel, Lloyd and Akino's indices at a fourdigit level of Standard International Trade Classification to estimate the level of Iran's intra-industry trade for the time of 1994-1998. Ziai, Bigdeli and Hassanpour (2004) used Grubel and Lloyd's index at a three digit level of Standard International Trade Classification (SITC) to measure intra-industry trade among Islamic Conference State Members for the time period of 1997-2001. Kalbasi et al., (2004) used for digit codes of SITC to measure the rate of Iran's intra-industry trade over 1997 to 2001 and concluded that the index of intraindustry trade between Iran and other countries is very low. Azarbayjani and Izadi (2006) employed Grubel, Lloyd and Akino's indices at a five digit level of Standard International Trade Classification (SITC) to examine Iran's commercial potential for 1998 to 2002. They also employed static indices for different types of trade at a four-digit level of SITC to estimate Iran's intra-industry trade with China. In the study conducted by Rasekhi (2007), the methodology used to measure Iran's intra-industry trade was developed for Iran is manufacturing industries. To do so, the level of Iran's intra manufacturing industry was determined for 1997 to 2003 . In mentioned study, indices introduced by Grubel and Lloyd and Fontagne and Freudenberg (1997) were used to determine intra static industry for plants and Brolhart's index was used to measure marginal intraindustry trade for manufacturing industries.

\section{Methodology}

Intra-industry trade refers to concurrent imports and exports of similar products developed by Grubel and Lloyd and were widely employed in measuring intra-industry trade. Grubel and Lloyd's index for Industry $\mathrm{j}$ is calculated through the following equation ${ }^{1}$ :

$G L=\frac{X j+M j-|X j-M j|}{X j+M j}=1-\frac{|X j-M j|}{X j+M j}$

Where $\mathrm{Xj}$ and $\mathrm{Mj}$ are export and imports within Industry $\mathrm{j}$, respectively. This index varies within the range of 0 to 1 . Full intra-industry trade is indicated as 1 and full inter-industry is shown as 0 based on this index.

The main development in the 1990s with regard to measuring intra-industry trade has been related to categorization of intra-industry trade into vertical intra-industry trade (VIIT) and horizontal intra-industry trade (HIIT). Horizontal/vertical intra-industry trade refers to concurrent imports and exports of products with different apparent features (qualities). Two significant approaches have been used for dividing intraindustry trades into different types:

- Index used for various types of trade by Fontagne and Freudenberg (1997) was built mainly on the approach developed by Abdol Rahman (1991).

- Index developed by Greenaway, Hine, and Milner (1995) was mainly based on Grubel and Lloyd's index.

Index used by Fontagne and Freudenberg (1997) is calculated in two stages: In the first stage and based on overlapping condition, the trade flow is divided into unilateral and bilateral trade. Based on this criterion, if the value of minority flow is at least $10 \%(\lambda=10 \%)$ of the majority flow, the trade for a group of products is bilateral. In other words:

$\frac{\operatorname{Min}\left(X k k^{\prime} i t, M k k^{\prime} i t\right)}{\operatorname{Max}\left(X k k^{\prime} i t, M k k^{\prime} i t\right)}>10 \%$

${ }^{1}$ Rasekhi, S. (2007). The methodology used for measuring intra-industry trade. A case study of Iran's Manufacturing Industry, pp 4-5. 
Where, Xkk' it and Mkk'it are indicative of imports and exports for Country $k$ with its business partner $k^{\prime}$ for Product $i$ in Year $t$, respectively. In the second stage, based on Dixit and Stiglitz's work (1977), it is assumed that differences in a products prices reflect the differences in the quality of the products. From a calculative view, products are regarded as similar if the difference in the unit value (UV) ${ }^{2}$ for imports and exports is less than $15 \%$, that is to say:

$\frac{1}{1+\alpha} \leq \frac{U V^{*} l i k t}{U V^{m} \ell i k t} \leq 1+\alpha$

$U V^{x} \ell i k t$ : Unit value for exports of product $\boldsymbol{\ell}$, industry $\mathbf{i}$, with business partner $\mathbf{k}$ in the time $\mathbf{t}$.

$U V^{m} \ell i k$ t: Unit value for imports of product $\boldsymbol{\ell}$, industry $\mathbf{i}$, with business partner $\mathbf{k}$ in the time $\mathbf{t}$.

Bilateral trade is classified into different types based on similarity conditions or GHM index. Accordingly, unit value for imports and exports is employed as follows:

$1+\alpha \leq \frac{U V^{*} \ell i k t}{\mathrm{UV}^{\mathrm{m}} \ell \text { ikt }} \leq 1-\alpha$

The overlap percentage $(\alpha)$ varies from 0 to 1 . If the proportion of the net unit value is placed outside Equation 4, intra-industry trade will be horizontal. In contrast, from the native country view if $1+\alpha>\frac{U V^{-}}{U V^{m}}$ , the exports are of high quality $\left(\right.$ VIIT $\left.^{H}\right)$ and if $1-\alpha<\frac{U V^{s}}{U V^{m}}$ the exports are of low quality.

The difference between Fontagne and Freudenberg's index (1997) and Greenaway, Hine, and Milner's index (1995) is related to the fact that $1-\alpha$ has been used in place of $\frac{1}{1+\infty}$ on the left side of Equation (3) which indicates that there is a kind of symmetry between the upper limit and the lower limit regarding the distance proportion from 1 . If the value of $\alpha$ ranges from 0 to 1 the result is always $\frac{1}{1+\alpha}<1$ - $\alpha$. For instance, if $\alpha=15 \%$ and if based on GHM approach, the proportion of unit vale is between $0.85 \leq \frac{U V V^{-\infty}}{U V^{-x}} \leq 1.15$, then the products are included in vertical distinction. However, based on FF approach, this proportion will be $0.87 \leq \frac{U V^{*}}{U V^{m x}} 1.15 \leq$ and, therefore, a number of products included in horizontal distinction based on GHM are now included in vertical distinction.

Product quality space (PQS): $\mathrm{PQS}$ is a square whose diameter is the geometrical locus of points where the unit values of exports and imports are equal. In this case, all bilateral trade flows are included in horizontal distinctions. The remaining space in the square is devoted to all possible export and imports unit values in the period under study. The square size is dependent on the way PQS is defined. For example, PQS can be studied as the changes in unit value during few years or the changes occurred in a product within a year or both. Coordinates of each unit value can be drawn in the PQS square. From the native country view, coordinates of the unit value in the above triangle and left-hand side of the square indicate products whose exports are of higher quality than their imports. In the lower triangle and the right hand side of the square, exports of goods are of a lower quality than their imports.

Products quality indices in intra-industry trade: An index developed based on Grubel and Lloyd's index, representing the product quality in intra-industry trade is introduced in this part of the study. The index is first used for quality distinction at the level of products. The related equation can be written in its simplest form as follows:

$\frac{H I I T}{I I T}=1-\frac{\|U V x-U V m\|}{(U V x+U V m)}$

Although this index is symmetrical, it is not able to distinguish between the qualities of products in bilateral trade. Since the country is regarded as constant it is not possible to distinguish between products included in VIIT $^{\mathrm{H}}$ and VIIT ${ }^{\mathrm{L}}$ in intra-industry trade flows. To solve this problem, the absolute value will be omitted from combined the net unit value, resulting in an index that is capable of distinguishing between VIIT ${ }^{\mathrm{H}}$ And VIIT $^{\mathrm{L}}$, as follows ${ }^{3}$ :

\footnotetext{
${ }^{2}$ Unit value for each product is obtained by dividing trade monetary value on the amount of the money, which gives the price per tonnage. Therefore, unit value will take the form of proportion of importation to exports or the other way round which is shown as $r$. Besides, a certain limit called $\alpha$ disperse percentage is chosen for dividing horizontal and vertical differentiation.

${ }^{3}$ Abdul, Azhar and Robert Elliott,(2006), on the Measurement of Product Quality in Intra- Industry Trade.
} 
$\mathrm{PQH}=1-\frac{w V x-U V m}{(U V x+U V m)}, \quad 0<\mathrm{PQH}<2$

Like Grubel and Lloyd's index, which measures the share of IIT in total trade flows, the above index can be regarded as an index for measuring product quality in IIT.

$\mathrm{PQH}$ index used for measuring vertical distinctions between products in intra-industry trade flow can be rewritten as follows:

$\mathrm{PQV}=1+\frac{U V x-U V m}{(U V x+U V m)}, \quad 0<\mathrm{PQV}<2$

In this case, if the bilateral trade has a similar quality (VIIT $=0$ ), PQV index will be equal to the unit. Eventually the sum total of indices for each level of IIT is equal to 2:

$P Q V+P Q H=2$ or $P Q V=2-P Q H$

\section{Figure 1: Product quality space (PQS)}

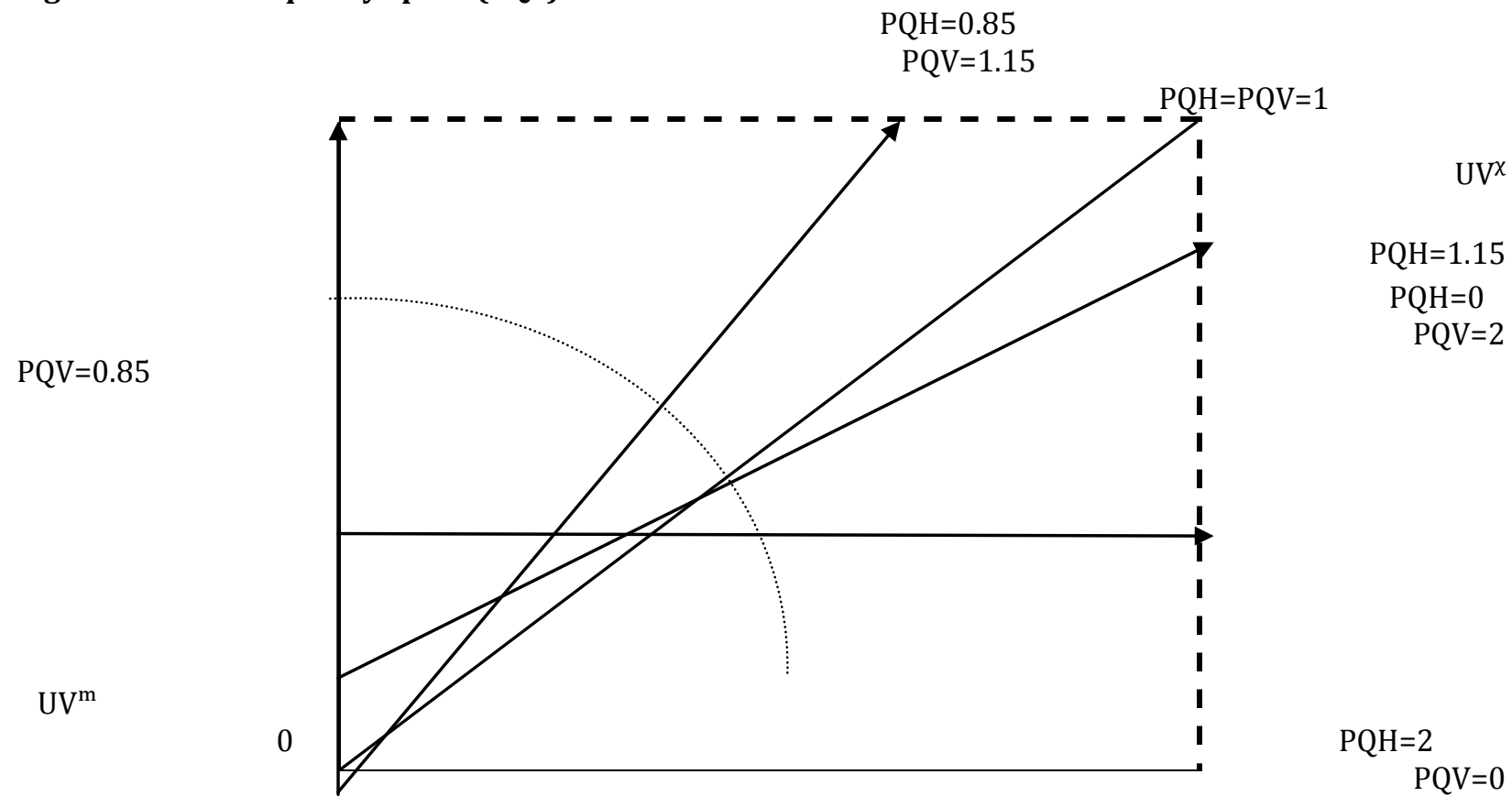

When the indices' value is between zero and two, it will be possible to distinguish between horizontal and vertical IIT. Naturally, the quality is reflected in product prices, which makes it possible to determine similarity with the defined limit. The question posed here is: Which percentage of costs in bilateral trade for manufacturing products is needed to determine vertical and horizontal distinction? In the case that exports and imports of a product at least cover $85 \%$ of costs (which is reflected in the price per tonnage of a product), the bilateral trade of the product will have a horizontal distinction but if they cover $50 \%$ of costs vertical intra-industry trade will be of high quality. In the former case, the distinctions can be determined as follows:

From the native country's view, intra-industry will be of high quality (VIIT ${ }^{\mathrm{H}}$ ) if $\mathrm{PQH}<0.85$ or it will be of low quality if $\mathrm{PQH}>1.15$. In the case that products have similar quality it will result in $0.85 \leq \mathrm{PQH} \leq 1.15$.

Applying the same reasons, we can write about PQV index; Intra- industry trade will be of high quality if PQV> 1.15 but it will be of low quality if $\mathrm{PQV}<0.85$. There will also be similar qualities (HIIT) if $0.85 \leq \mathrm{PQH} \leq 1.15$.

The main difference between the POV, PQH, GHM, and FF indices is that the two indices of GHM and FF use unit value for measuring product quality, given $\alpha$ value, while POV and PQH indicators are calculated based on Grubel index. One the features of this symmetrical index is that it is possible that levels of quality products differences in a product group or in a part of the industry to be rated and compared with regard to the amount of horizontal and vertical intra-industry trade. 


\section{Results and Discussion}

A significant part of Iran's foreign trade with G-8 state members is performed with European countries and a top of them, Germany is regarded as one of the most important partners for Iran's foreign trade. Table 1 represents Iran's total foreign trade with G-8 countries during the period of 2001 to 2009 . The first three Iran's business partners in 2003 were Germany, France, and Italy. These three countries allotted 23.26\% of Iran's foreign trade with G-8 countries to themselves in 2003. In 2006, the amount of Iran's foreign trade with G-8 countries has increased from $\$ 11.5$ billion to $\$ 14.5$ billion. However, the share of three other countries (Germany, France, and Italy) decreased to $18.47 \%$. Besides, the share of five countries (Japan, Russia, Britain, Canada, and the U.S) has undergone a sharp decrease from $17.67 \%$ to $8.43 \%$ in 2003. In 2009, the bulk of Iran's foreign trade with G-8 state members increased to about \$ 15 billion. As it can be seen in the table, Japan ranked the third position in 2009. However, the share of G-8 state members in Iran's foreign trade has decreased sharply compared to previous years and fell from $35.33 \%$ in 2003 to 18.96 in 2009. In the coming sections, Iran's intra-industry trade with G-8 state members is investigated. Table 1 indicates that in 2003 the main Iran's business partners are the U.S., Russia, and Canada. In that year, the shares of transaction for these countries in Iran's intra-industry were determined as $11.28,9.90$, and $4.73 \%$, respectively. In the same year the share of intra-industry with other countries especially Japan has decreased. In 2006, Iran's foreign trade with G-8 state members improved to some extent and the U.S intra-industry trade increased from $11.28 \%$ to 23.05. This increase for Japan has been significant, i.e. from 0.15 to 4.90 . However, Canada's intra-industry trade has increased to $2.71 \%$ compared to that of the previous year. In addition, Russia having a share of 6.95 for its intra-industry trade occupied a middle position between the U.S and Japan. In 2009, Iran's intraindustry business partners were, Russia, Canada, and the U.S. the share of Iran's intra-industry trade with these countries are 10.56, 7.88, and 6.01, respectively. The amount of Russia's intra-industry trade has increased compared to its amount in 2003. However, as it can be seen the share of intra-industry trade for the U.S has decreased sharply in comparison to its trade in 2006. The same is also true for Japan. Although the share of Iran's intra-industry trade with G-8 members has increased in that year over 2003, it has witnessed a decrease compared to its trade in 2006 , which may be due to changes in the composition of major trading partners in favor of inter-industry trade. In other words, the share of countries whose trade is inter-industry has increased in Iran's foreign trade. The general expectation is that the level of Iran's IIT with advanced industrial countries is mainly in the form of inter-industry trade. Evaluation of Iran's Intra-industry trade with G-8 state members reflects the same issue.

One of the reasons for the low level of Iran's intra-industry trade with G-8 state members is related to the great difference between Iran's high level of growth and development compared to that of G-8 state members. Another reason accounting for the low level of a country's intra-industry trade is the low share of manufactured goods in the country's exports. Based on theoretical basis of intra-industry trade, concurrent imports and exports of distinct products are mainly related to manufacturing industry sector because such products are of high distinction level and the savings resulting from their scale. Therefore, those countries that have an advanced manufacturing industry possess a significant intra-industry trade especially among similar countries. In addition, geographical proximity can result in the formation and the development of intra-industry trade. One of the reasons for the low level of intra-industry trade for the mentioned countries is associated with geographical proximity as these countries are geographically located farther away from Iran. Table 2 shows different kinds of Iran's bilateral trade with G-8 state members based on similarity index (GHM) with similarity degree of $15 \%(\alpha=15)$ during 2001-2009. As the table indicates, employing similarity index (GHM) with similarity degree of 15\% during 2001-2009, the amount of Germany's horizontal intraindustry trade was $51.53 \%$ and its vertical intra-industry trade was $48.45 \%$.these results compared to similarity degree of $25 \%$ in which horizontal intra-industry trade $52.7 \%$ and vertical intra-industry trade was $47.29 \%$, it will become clear that Germany's horizontal and vertical intra-industry trade has dropped. For other countries, the amount of horizontal intra-industry trade is on the average high, among which the U.S has the highest rate of vertical intra-industry trade (86.42\%). Japan and Canada occupied the second and the third positions, respectively. The amount of vertical intra-industry trade is relatively high based on similarity degree of $25 \%$ in Table 3 but compared to similarity degree of $15 \%$ the share of horizontal intra-industry trade has risen. For instance, the share of horizontal intra-industry trade with similarity degree of $15 \%$ for France has been equal to $33.06 \%$ but based on similarity degree of $25 \%$ it has risen to $47.43 \%$. 
Table 1: Iran's total trade and the share of foreign and intra-industry trade (based on Grubel and Lloyd's index) with G-8 state members during 2001-2009 (\$-\%)

\begin{tabular}{|c|c|c|c|c|c|c|c|c|c|c|c|c|c|c|}
\hline $\begin{array}{l}200 \\
\mathbf{R} \\
\mathbf{a} \\
\mathbf{n} \\
\mathbf{k}\end{array}$ & $\begin{array}{l}\text { Shar } \\
\text { e of } \\
\text { IIT }\end{array}$ & $\begin{array}{l}\text { Iran' } \\
\mathrm{s} \\
\text { shar } \\
\mathrm{e} \text { of } \\
\text { total } \\
\text { trade }\end{array}$ & Trade value & $\begin{array}{l}\text { Count } \\
\text { ry }\end{array}$ & $\begin{array}{l}2006 \\
\text { Ran } \\
k\end{array}$ & $\begin{array}{l}\text { Shar } \\
\mathrm{e} \text { of } \\
\text { IIT }\end{array}$ & $\begin{array}{l}\text { Iran' } \\
\mathrm{s} \\
\text { shar } \\
\mathrm{e} \text { of } \\
\text { total } \\
\text { trad } \\
\mathrm{e}\end{array}$ & Trade value & $\begin{array}{l}\text { countr } \\
\mathrm{y}\end{array}$ & $\begin{array}{l}2003 \\
\text { Ran } \\
\mathrm{k}\end{array}$ & $\begin{array}{l}\text { Shar } \\
\mathrm{e} \text { of } \\
\text { IIT }\end{array}$ & $\begin{array}{l}\text { Iran' } \\
\mathrm{s} \\
\text { shar } \\
\mathrm{e} \text { of } \\
\text { total } \\
\text { trad } \\
\mathrm{e}\end{array}$ & Trade value & $\begin{array}{l}\text { Countr } \\
\mathrm{y}\end{array}$ \\
\hline 1 & 3.59 & 6.57 & $4,998,422,759$ & $\begin{array}{l}\text { Germa } \\
\text { ny }\end{array}$ & 1 & 1.94 & 9.99 & $\begin{array}{l}5,433,169,3 \\
60\end{array}$ & $\begin{array}{l}\text { Germa } \\
\text { ny }\end{array}$ & 1 & 1.87 & $\begin{array}{l}10.4 \\
6\end{array}$ & $\begin{array}{l}3,387,253,9 \\
54\end{array}$ & $\begin{array}{l}\text { Germa } \\
\text { ny }\end{array}$ \\
\hline 2 & 5.39 & 3.05 & $2,322,168,122$ & Italy & 2 & 7.53 & 4.34 & $\begin{array}{l}2,362,324,5 \\
70\end{array}$ & Italy & 2 & 1.88 & 7.10 & $\begin{array}{l}2,297,939,6 \\
11\end{array}$ & France \\
\hline 3 & 1.24 & 2.34 & $1,783,015,051$ & Japan & 3 & 4.75 & 4.14 & $\begin{array}{l}2,254,633,3 \\
55\end{array}$ & France & 3 & 4.45 & 5.70 & $\begin{array}{l}1,846,744,3 \\
39\end{array}$ & Italy \\
\hline 4 & 5.86 & 2.29 & $1,738,806,856$ & $\begin{array}{l}\text { Engla } \\
\text { nd }\end{array}$ & 4 & 4.90 & 2.91 & $\begin{array}{l}1,581,206,5 \\
18\end{array}$ & Japan & 4 & 0.15 & 4.19 & $\begin{array}{l}1,357,405,1 \\
89\end{array}$ & Japan \\
\hline 6 & $\begin{array}{l}10.5 \\
6\end{array}$ & 1.60 & $1,217,357,410$ & Russia & 6 & 6.95 & 1.79 & $973,435,059$ & Russia & 6 & 3.37 & 2.84 & $920,910,204$ & $\begin{array}{l}\text { Englan } \\
\mathrm{d}\end{array}$ \\
\hline 7 & 7.88 & 0.46 & $346,911,843$ & $\begin{array}{l}\text { Canad } \\
\text { a }\end{array}$ & 7 & 2.71 & 0.52 & $283,312,195$ & Canada & 7 & 4.73 & 0.74 & $240,564,590$ & Canada \\
\hline 8 & 6.01 & 0.40 & $907,846,752$ & $\begin{array}{l}\text { The } \\
\text { U.S }\end{array}$ & 8 & $\begin{array}{l}23.0 \\
5\end{array}$ & 0.42 & $227,472,127$ & $\begin{array}{l}\text { The } \\
\text { U.S }\end{array}$ & 8 & $\begin{array}{l}11.2 \\
8\end{array}$ & 0.6 & $195,200,836$ & $\begin{array}{l}\text { The U. } \\
\text { S }\end{array}$ \\
\hline 100 & & & $\begin{array}{l}76,062,770,44 \\
0\end{array}$ & $\begin{array}{l}\text { Iran's } \\
\text { total } \\
\text { trade }\end{array}$ & 100 & & & $\begin{array}{l}54,397,617, \\
808\end{array}$ & $\begin{array}{l}\text { Iran's } \\
\text { total } \\
\text { trade }\end{array}$ & 100 & & & $\begin{array}{l}32,375,481 \\
776\end{array}$ & $\begin{array}{l}\text { Iran's } \\
\text { total } \\
\text { trade }\end{array}$ \\
\hline
\end{tabular}

Source: research findings: www.tccim.ir

As it was mentioned previously, intra-industry trade is divided into horizontal and vertical intra-industry trade based on Greenaway, Hine, and Milner's similarity index (GHM). If the proportion of exports unit to imports $\left(\frac{U V x}{U V m}\right)$ is greater than $1+\alpha$ the vertical intra-industry trade will be of high quality. On the other hand, when the value of exports unit to imports $\left(\frac{U V x}{U V m}\right)$ is less than 1 - $\alpha$ the vertical intra-industry trade will be of low quality. In addition, the values between these two extremes are associated with horizontal intra-industry trade. Table 4 presents a general comparison between GHM index with similarity degrees of 15 and $25 \%$ and PQV index. As the table suggests, during 2001 to 2009. The immediate observation is that all three disentangling techniques show that, in general, Iran exports lower quality variety of product to all these countries. For example, for most widely used measure, the GHM index where $\alpha=15 \%$, HIIT accounts for less than $10 \%$ of all IIT but low quality exports accounting for around two-thirds of all IIT. Taking Germany as an example, the highest share of intra-industry trade for Germany belongs to vertical intra-industry trade with a low quality. A similarity degree of $25 \%$ shows the same number of products belong to vertical intra-industry trade with a low quality. we can see that for $\mathrm{GHM}=15 \% 37$ products $(9.04 \%)$ are horizontally differentiated and 259 products $(63.32 \%)$ are classified as VIITL. This compares with $58(13.93 \%)$ and 247 (60.39\%) for HIIT and VIITL respectively for GHM $=25 \%$ meaning that using this similarity degree $(25 \%)$ shows more products as HIIT and less vertically high quality IIT. A comparison of PQV index and GHM similarity index indicates that $\mathrm{PQV}$ index put a greater number of products in the vertical intra-industry trade group. Generally, for the other countries it can be concluded that a decrease in the similarity degree from $25 \%$ to $15 \%$ a greater number of products will be placed in the vertical intra-industry trade group with a high quality. Compared to PQV index, GHM index places more products in the vertical distinction category. In other words, products are qualitatively similar but are different with regard to their appearance. It could be argued that AE measure is more accurately capturing true horizontal and vertical IIT and would explain the apparent anomaly in the IIT literature that seems to demonstrate that the vast majority of IIT is vertically differentiated and more akin to inter- industry trade. Therefore, during 2001 to 2009 Iran's intra-industry trade with G-8 state members was included in vertical intra-industry trade with different product groups of low quality. 
Table 2: The share of different types of Iran's intra-industry with G-8 state members on the average with similarity degree of $15 \%$ during 2001-2009 (\%)

\begin{tabular}{rcccccccc}
\hline Canada & France & Russia & Japan & Italy & $\begin{array}{r}\text { The } \\
\text { U.S.A }\end{array}$ & England & Germany & Average \\
\hline 27.02 & 33.06 & 54.47 & 21.44 & 39.84 & 13.57 & 44.34 & 51.53 & Vertical \\
72.97 & 66.93 & 45.52 & 78.56 & 60.15 & 86.42 & 55.65 & 48.45 & Horizontal \\
\hline
\end{tabular}

Source: Research findings

Table 3: The share of different types of Iran's intra-industry with G-8 state members on the average with similarity degree of $15 \%$ during $2001-2009$ (\%)

\begin{tabular}{rrrrrrrrr}
\hline Canada & France & Russia & Japan & Italy & $\begin{array}{r}\text { The } \\
\text { U.S.A }\end{array}$ & England & Germany & Average \\
\hline 35.59 & 47.43 & 57.26 & 27.20 & 45.47 & 14.33 & 53.39 & 52.7 & Vertical \\
64.40 & 52.57 & 42.73 & 72.80 & 54.25 & 85.66 & 46.61 & 47.29 & Horizontal \\
\hline
\end{tabular}

Source: Research findings

Table 5 shows goods groups that have the highest IIT index over the period 2001-2009. This table identifies the composition of goods in Iran's intra- industry trade in specified period. Based on the table, the most important product groups in Iran's intra- industry trade in period 2001-2009 belongs to plates, sheets and strips made of refined copper, handbag, chandeliers and lighting fixtures, with index 99.98, 99.85 and 99.71 respectively. The lowest IIT index in that period belongs to compound stabilizers for rubber products and antioxidant with index 97.58. Therefore, product groups in bilateral trade of Iran with G-8 members relatively are manufactured goods. In other words, manufactured goods has an important roles respect to disposability goods

Table 4: A comparison of different types of Iran's intra-industry with G-8 state members and their classification based on product quality during 2001-2009 (No.- \%)

\begin{tabular}{|c|c|c|c|c|c|c|c|c|c|}
\hline \multicolumn{3}{|c|}{ GHM 15\% } & \multicolumn{3}{|c|}{ GHM 25\% } & \multicolumn{4}{|l|}{ PQV } \\
\hline VL & VH & $\mathbf{H}$ & VL & VH & $\mathbf{H}$ & $\mathbf{V L} *$ & $\mathbf{V H} *$ & $\mathbf{H}^{*}$ & Country \\
\hline 259 & 113 & 37 & 247 & 104 & 58 & 247 & 97 & 65 & Germany \\
\hline $63.32 \%$ & $27.62 \%$ & $9.04 \%$ & $60.39 \%$ & $25.42 \%$ & $13.93 \%$ & $14.18 \%$ & $23.71 \%$ & $15.86 \%$ & \\
\hline 195 & 68 & 20 & 184 & 64 & 36 & 182 & 61 & 42 & England \\
\hline $68.42 \%$ & $23.85 \%$ & $7.01 \%$ & $64.56 \%$ & $22.45 \%$ & $12.63 \%$ & $63.85 \%$ & $21.40 \%$ & $14.73 \%$ & \\
\hline 24 & 5 & 2 & 23 & 6 & 2 & 22 & 5 & 4 & U.S.A \\
\hline $77.41 \%$ & $16.12 \%$ & $6.45 \%$ & $74.19 \%$ & $19.35 \%$ & $6.45 \%$ & $70.96 \%$ & $16.12 \%$ & $12.9 \%$ & \\
\hline 260 & 74 & 18 & 248 & 66 & 38 & 247 & 62 & 44 & Italy \\
\hline $73.65 \%$ & $20.96 \%$ & $5.09 \%$ & $70.25 \%$ & $18.69 \%$ & $10.76 \%$ & $69.97 \%$ & $17.56 \%$ & $12.46 \%$ & \\
\hline 47 & 29 & 4 & 47 & 27 & 6 & 47 & 24 & 9 & Japan \\
\hline $58.75 \%$ & $36.25 \%$ & $5 \%$ & $58.75 \%$ & $33.75 \%$ & $7.5 \%$ & $58.75 \%$ & $30 \%$ & $11.25 \%$ & \\
\hline 57 & 48 & 21 & 55 & 46 & 25 & 55 & 46 & 25 & Russia \\
\hline $45.23 \%$ & $37.09 \%$ & $16.66 \%$ & $43.65 \%$ & $36.5 \%$ & $19.84 \%$ & $43.65 \%$ & $36.5 \%$ & $19.84 \%$ & \\
\hline 108 & 24 & 6 & 101 & 22 & 15 & 101 & 21 & 16 & France \\
\hline $78.26 \%$ & $17.39 \%$ & $4.34 \%$ & $73.18 \%$ & $15.94 \%$ & $10.86 \%$ & $73.18 \%$ & $15.21 \%$ & $11.59 \%$ & \\
\hline 89 & 25 & 7 & 82 & 24 & 15 & 82 & 22 & 17 & Canada \\
\hline $73.55 \%$ & $20.66 \%$ & $5.78 \%$ & $67.76 \%$ & $19.83 \%$ & $12.39 \%$ & $67.76 \%$ & $18.18 \%$ & $14.04 \%$ & \\
\hline
\end{tabular}

Source: Research findings

* The first row represents the number of products and the second one shows the share of products within intra-industry trade.

* VL: low quality horizontal intra-industry trade

* VH: High quality vertical intra-industry trade

${ }^{*} \mathrm{H}$ : Horizontal intra-industry trade

Table 5: Product groups with highest IIT(based on Grubel and Lloyd's index) during 2001-2009(\%)

\begin{tabular}{lll}
\hline Rank & IIT index & Description of goods groups \\
\hline 1 & $99 / 98$ & Plates, sheets and strips made of refined copper \\
2 & $99 / 85$ & Handbag \\
3 & $99 / 71$ & Hanging chandeliers and other lighting fixtures for installation \\
\hline
\end{tabular}




\begin{tabular}{lll}
\hline 4 & $99 / 51$ & Source cooperage, barrels and containers such as peat with 300 liters capacity \\
5 & $99 / 45$ & Citric acid \\
6 & $99 / 42$ & Food products made from flour, without cocoa \\
7 & $99 / 19$ & Mineral water and carbonated and unsweetened water \\
8 & $98 / 92$ & Color television receivers and audio and video recording equipment \\
9 & $98 / 40$ & Iodine \\
10 & $97 / 58$ & Compound stabilizers for rubber products and antioxidants \\
\hline
\end{tabular}

Source: research findings: www.tccim.ir

\section{Conclusion and Recommendations}

The present study has examined Iran's intra-industry trade with G-8 state members at a four-digit level of harmonized system of Commodity Description and Coding (HS) for the time of 2001-2002. Based on the obtained results, it was found that the present study was the first serious study dealing with the measurement of intra-industry trade, which was conducted, first by Grubel and Lloyd (1975). The most significant development in this regard was related to the classification of different intra-industry trade by Abdol Rahman. Then, Azhar and Eliot, building upon Grubel and Lloyd's index, developed attempted to determine product quality in bilateral trade. The results of the present study indicate that:

- Iran's intra-industry trade with G-8 state members is at a low level and thus, a major part of intraindustry trade with G-8 state members is in the form of inter-industry trade. However, intra-industry trade with G-8 state members has been improved during the mentioned period.

- Vertical intra-industry trade comprises a significant share of Iran's bilateral trade with G-8 state members while the horizontal intra-industry trade as a part of Iran's bilateral trade with G-8 state members has been increased for the time under study.

- Iran's vertical intra-industry trade with G-8 state members includes products of low quality. The development in Iran's intra-industry trade can lead to an increase in the exports of industrial products. As a result, to gain a greater share in the world market it is needed to increase the level of vertical intra-industry trade. To do so, serious attention must be paid to products quality. Accordingly, the promotion of research and development (R\&D), improvement of production technologies, enhancement of the quality of factors of productions, attention to direct foreign investments on manufacturing industries, and active participation in economic convergences are regarded vital. In order to improve horizontal intra-industry trade it is essential to focus on horizontal products distinction based on the target market taste, attention to innovation, the use of global market capacity to utilize savings gained from the scale especially for capital-consumed industries, reduction of unnecessary spending, and improvement of competitive power in the global arena.

\section{References}

Abd-El-Rahman, K. (1991). Firm's Competitive and National Comparative Advantages as Join Determinants of Trade Composition. Review of World Economics/Weltwirtschaftliches Archive, 127(1), 83-97.

Azarbayjani, K. \& Izadi, G. (2006). Iran's intra-industry with China: a new perspective. Iran's Economic Quarterly Journal, 26, 81-99.

Azhar, A. K. \& Elliott, R. J. R. (2006). On the Measurement of Product Quality in Intra-Industry Trade. Review of World Economic, 142, 476-495.

Balassa, B. (1966). Tariff Reductions and Trade in Manufactures among the Industrial Countries. American Economic Review, 56, 466-473.

Bernard, A. B. \& Jensen, B. (2001). Why some Firms Export? The Review of Economics and Statistics, MIT Press, 86(2), 561-569.

Bernard, A. B., Redding, S. \& Schott, P. (2005). Heterogeneous Firms and Comparative Advantage. NBER Working Paper, 10068.

Brander, J. \& Krugman, P. (1983). A Reciprocal Dumping Model of International Trade. Journal of International Economics, 15 (3-4), 313-321. 
Chang, S. C. (2009). Horizontal and Vertical Intra-industry Trade and Firm's Investment Strategies: Evidence from the IT Industry in the Asian, EU and US Markets. Global Economic Review, 38, 63-76.

Clark, D. P. (2006). Country and Industry-Level Determinants of Vertical Specialization Based Trade. International Economic Journal, 20(2), 211-225.

Dixit, A. K. \& Stiglitz, J. E. (1977). Monopolistic Competition and Optimum Product Diversity. American Economic Review, 67, 297-308.

Eaton, J. \& Kierzkowski, H. (1984). Oligopolistic Competition, Product Variety, and International Trade. In KIERZKOWSKI, H. (eds.), Monopolistic Competition and International Trade. New York [etc.] : Oxford University Press.

Falvey, R. E. (1981). Commercial policy and intra-industry trade. Journal of International Economics, 11, 495-511.

Falvey, R. E. \& Kierzkowski, H. (1985). Product Quality Intra-Industry Trade and (Im) Perfect Competition , in Kierzkowski, H. (ed.), Protection and Competition in international Trade, Blackwell: Oxford.

Flam, H. \& Helpman, E. (1987). Vertical Product Differentiation and North-South Trade. American Economic Review, 77, 810-822.

Fontagne, L. \& Freudenberg, M. (1997). Intra-Industry Trade: Methodological Issues Reconsidered. CEPII Working paper 97-102.

Greenaway, D., Hine, R. C. \& Milner, C. (1995). Vertical and Horizontal Intra-Industry Trade: Some CrossSectional Evidence for the UK. Economic Journal, 105, 1505-1519.

Greenaway, D., Milner, C. R. \& Elliott, R. J. R. (1999). UK Intra-Industry Trade with the EU North and South. Oxford Bulletin of Economics and Statistics, 61, 365-384.

Grubel, H. \& Lloyd, P. (1975). Intra-Industry Trade. London: Macmillam.

Hallak, J. C. \& Schott, P. K. (2005). Estimating Cross - Country Differences in Product Quality. The Quarterly Journal of Economics, Oxford University Press, 26(1), 417-474.

Havrylyshyer, O. \& Kunzel, P. (1997). Intra-Industry Trade of Arab Countries: An Indicator of Potential Competitiveness. International Monetary Fund, 18(2).

Helpman, E. (1981). International Trade in the Presence Product Differentiation, Economies of Scale and Monopolistic Competition. Journal of International Economics, 11, 305-340.

Kalbasi, H., Raeesi Ardali, G. H. \& Raeesi, M. (2004). Estimation of Iran's intra-industry trade. Iranian Journal of Economic Research, 20, 55-79.

Krugman, P. R. (1979). Increasing Returns, Monopolistic Competition and International Trade. Journal of International Economics, 9, 469-479.

Krugman, P. R. (1980). Scale Economies, Product Differentiation and the Pattern of Trade. American Economic Review, 70(5), 950-959.

Krugman, P. R. (1981). Intra-Industry Specialization and Gains From Trade. Journal of Political Economy, 89(70), 959-973.

Lancaster, K. (1980). Intra-Industry Trade under Perfect Monopolistic Competition. Journal of International Economics, 10, 151-175.

Leitão N. C. \& Faustino, H. (2008). Intra-Industry Trade in the Food Processing Sector: The Portuguese Case. Journal of Global Business and Technology, 4(1), 49-58.

Leitão, N. C. \& Faustino, H. (2009). Intra-Industry Trade in the Automobile Components Industry: An Empirical Analysis, Journal of Global Business and Technology, 5(1), 31-41.

Nafari, A. \& Rasekhi, S. (2002). Estimation of Iran's Intra-industry trade. Business Quarterly Journal, 25, 1-20.

Rasekhi, S. (2007). A methodology for measuring intra-industry trade: A case study of Iran is manufacturing industries. Journal of Economic Studies, 81, 61-84.

Shaked, A. \& Sutton, J. (1984), Natural Oligopolies and International Trade. In H. Kierzkowski (ed.). Monopolistic Competition and International Trade. Oxford: Oxford University Press.

Wakasugi, R. (2007). Vertical Intra-Industry Trade and Economic Integration in East Asia. Asian Economic Papers, 6, 26-45.

Yoshida, Y. N. C., Leitão, N. C. \& Faustino, H. (2009). Vertical Intra-Industry Trade and Foreign Direct Investment between Japan and European Countries. Atlantic Economic Journal, 37, 351-365.

Zhang, Y. \& Clark, D. P. (2009). Pattern and Determinants of United States' Intra-Industry Trade. The International Trade Journal, 23, 325-356.

Ziai-Bigdeli, M. T. \& Hassan, P. Y. (2004). A study of Intra-industry trade of Islamic Conference (OIC) Member States. Business Quarterly Journal, 31, 91-125. 